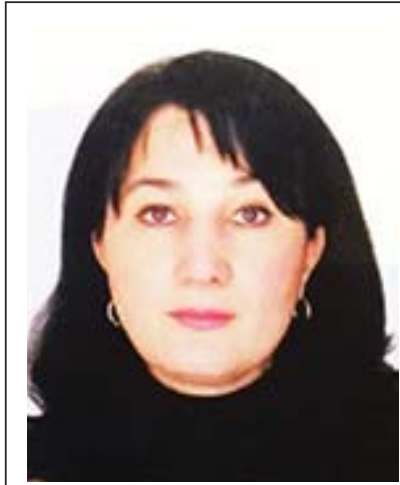

М.Ч. Чшиева
DOI 10.23671/VNC.2018.4.23788

\title{
СТРАНИЦЫ ПРОШЛОГО ГГАУ: ВЗГЛЯД В БУДУЩЕЕ
}

\author{
(к 100-летию со дня образования)
}

\section{М.Ч. Чшиева*}

Аннотация. Горскому государственному аграрному университету исполняется 100 лет. Не каждый вуз может гордиться такой богатой историей. Университет был основан в условиях революции, гражданской войны и иностранной интервенции. В это тяжелое время в Осетии, как и во всей России, не был решен аграрный вопрос, а на Кавказе не хватало своих научных кадров и учебных заведений, которые бы их готовили. Сегодня, спустя 100 лет, перед вузом, как в целом перед всей страной, опять стоят поистине революционные задачи, как когда-то в период его создания. Это задачи, поставленные Президентом РФ в майских указах: обеспечение продовольственной безопасности страны, вхождение России в пятерку развитых стран мира, достижение чего невозможно без рывка в научной сфрере.

У аграрного университета имеется богатый научно-практический опыт. В статье проанализирована деятельность ученых, с именами которых связаны жизненно важные страницы истории университета. При этом опыт, накопленный за 100-летнюю историю существования Горского ГАУ, большей частью не востребован. Соглашаясь с точкой зрения советника Президента РФ академика С.Ю. Глазьева, отметим, что в условиях гибридной войны, идущей с вытягиванием ресурсов из России и постсоциалистических стран, огромную роль играет обеспечение продовольственной безопасности страны, которой невозможно достичь без развития аграрной науки.

Ключевые слова: первый советский политехнический институт, становление аграрной науки на Северном Кавказе, научные школы В.Ф. Раздорского, Д. А. Тарноградского, С.Х. Дзанагова, С.А. Бекузаровой, Б.Б. Басаева.

Наша страна, как и 100 лет назад, находится в непростых условиях. За 25 лет, за счет распада Советского Союза и мировой социалистической системы, наш геополитический противник получил более триллиона долларов, сотни тысяч наших специалистов, миллиарды тонн наших природных ресурсов и множество уникальных технологий [1, 4]. В мировом сельском хозяйстве также произошла мощная технологическая революция: за четверть века все регионы мира удвоили объемы производства продовольствия: и Африка, и Азия, и Америка. Например, Китай на меньших сельхозплощадях производит 600 млн тонн зерна, а мы лишь 90, хотя можем выращивать не менее 200 млн тонн. Но в условиях западных санкций и контроля нерезидентов над более чем половиной промышленных предприятий, нам перекрыт доступ к новым технологиям.

По подсчетам экс-директора НИИ статистики Госкомстата России доктора экономических наук Василия Симчеры, доля иностранного капитала в пищевой промышленности превышает 60 \% и продолжает устойчиво расти. В большинстве сегментов российского рынка продуктов питания наибольшая доля оказалась в руках иностранных корпораций:

- почти 60 \% рынка молока;

- более 70 \% рынка соковой продукции;

- порядка 80 \% рынка замороженных овощей и фрруктов;

- более 90 \% рынка плодовоовощной консервации;

- более 80 \% рынка пивоварения.

Как только на российском рынке появляется сильное отечественное производство или бренд, пользующийся популярностью у потребителя, они сразу скупаются иностранными корпорациями [2].
Так предприятия-производители «исконно российских» товаров оказались в руках иностранцев. Например, молочные продукты «Домик в деревне» и «Веселый молочник», вода «Ессентуки», соки «Фруктовый сад», «Любимый», «Тонус», «Я», «Добрый», квас «Кружка и бочка», печенье «Юбилейное», шоколад «Воздушный» со слоганом «Россия - щедрая душа», вафельный торт «Причуда», конфреты «Каркунов» принадлежат США; «Простоквашино» и «Растишка», а также автомобиль «Лада» Франции; конфеты «Белочка» и «Мишка на севере» - Норвегии; мороженое «48 копеек» - Швейцарии; пиво «Балтика», «Невское», «Жигулевское» - Дании; пиво «Охота», «Три медведя» - Нидерландам; пиво «Клинское» - Бельгии т. д. [2]. Во многих стратегических отраслях экономики доля импорта в потреблении превышает 80 процентов, что создает потенциальную угрозу, как для национальной безопасности, так и конкурентоспособности России в целом.

Сектор торговли также почти полностью захвачен иностранным капиталом. По подсчетам доктора экономических наук, профессора МГИМО В.Ю. Катасонова, доля организаций с участием иностранного капитала составила 81,4 \% всего уставного капитала [3]. Это означает, что торговые нерезиденты поставили под контроль всю страну, создав сети своих магазинов на всей территории от Калининграда до Сахалина. Их названия хорошо известны: «Пятерочка» (Нидерланды), «Перекреток» (Нидерланды), «MetroCash\&Carry» (Германия), «Лента» (Британские Виргинские острова), «Глобус» (Кипр), «Магнит» (Кипрский офшор Lavreno Ltd.), «Копейка», «Мы», «Меркадо суперцентр», «Универсам» (все - Нидерланды) и др. [3]. 
Пока эти торговые сети ведут конкурентную борьбу с отечественными торговыми точками и между собой, они могут продавать товары по демпинговым ценам, но когда их останется несколько, между ними может быть заключен картельный сговор и установлен контроль над российской торговлей. Это создает угрозу национальной безопасности страны. «Розничная торговля, особенно жизненно необходимыми товарами (прежде всего, продовольствием), - не просто «сектор экономики». Это важнейший элемент экономической и социальной инфрраструктуры. По команде «оттуда» спруты могут в любой момент заблокировать снабжение населения продовольствием и иными предметами первой необходимости, как это уже было в России в феврале 1917 г.», когда была свергнута династия Романовых [3].

Также за 20 лет быстрыми темпами шло разрушение российской промышленности. Численность работников машиностроения за это время сократилась в 3,7 раза. В стране почти полностью уничтожены отечественное тракторостроение, комбайностроение (в 2017 г. выпущено только 2450 штук тракторов по сравнению с 213,6 тыс. в 1990 г., т. е. в 87 раз меньше, как в первые послевоенные годы в РСФСР; в 2017 г. - 5777 комбайнов, вместо 56,5 тыс. в 1990 г., почти в 10 раз меньше. За 1990-2010 гг. производство тракторных плугов сократилось в 57 раз, культиваторов - в 26 раз, сеялок - в 28 раз, косилок - в 7,5 раза, доильных установок - в 12,8 раза). В 1998 г. доля продукции машиностроения и металлообработки в вывозе из РСФСР сократилась с 34,7 \% до 5,8 \% в 2006 г. [4]. В семеноводстве России монопольное положение захватывают такие мировые транснациональные корпорации, как Монсанта, Байер и др., выпускающие генномодифицированную продукцию, влияние которой на здоровье населения не до конца изучено. Гербициды этой компании вызывают онкологические заболевания. Во Франции и других европейских странах против нее были возбуждены уголовные процессы.

Президентом РФ были поставлены жизненно важные задачи обеспечения продовольственной безопасности России и вхождения в пятерку развитых стан мира. Но это невозможно, когда, например, при производстве сыра используется испанское оборудование, на котором, с одной стороны,

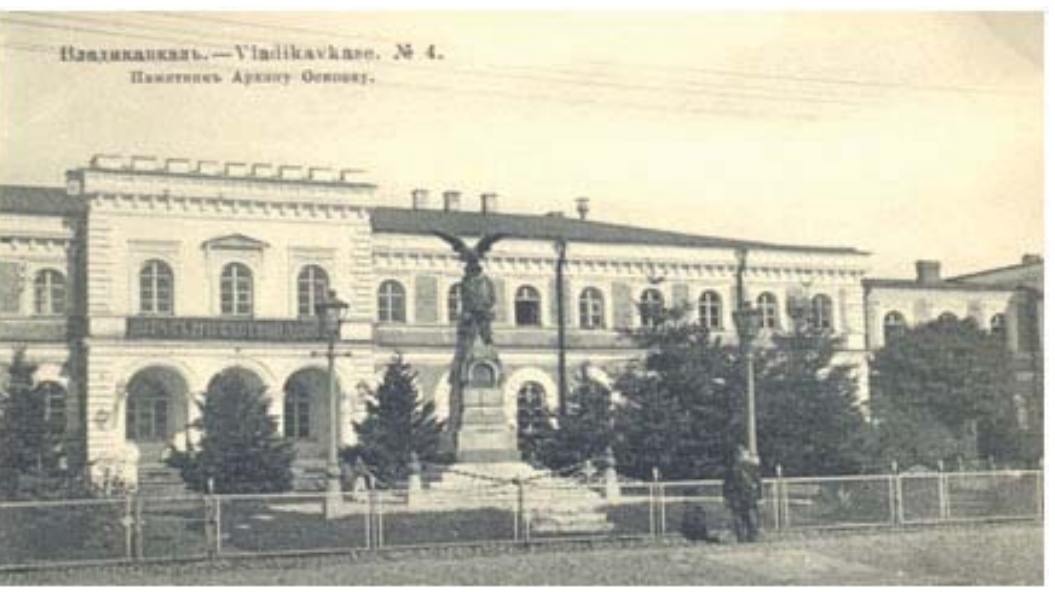

Фomo 1. До революции 1917 г. здесь находился Штаб 21-й пехотной ивизии, Управление Владикавказского воинского начальника, памятник А. Осипову и Терская инженерная дистанция. В 70-е XX в. на этом месте построен главный корпус ГГАУ

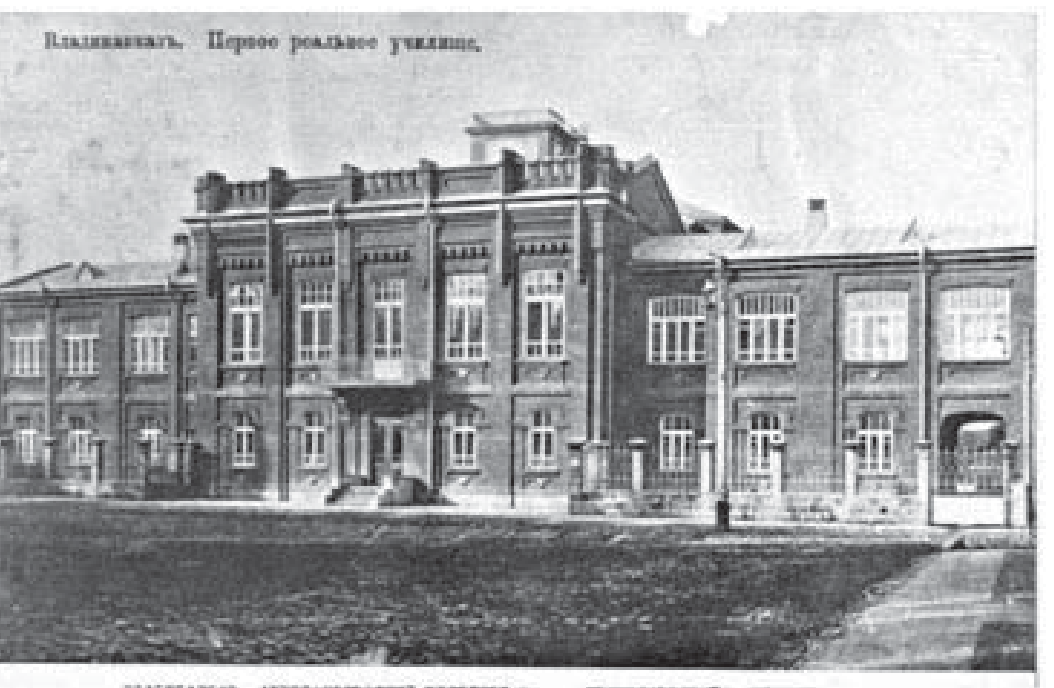

Фото 2. Первое реальное училище - современный корпус агрономического факультета ГГАУ

установлены брикеты пальмового масла, а с другой - пакеты с сухим молоком из Белоруссии, и из этого делают сыр. То есть если с полок магазинов убрать весь фральсификат, то станет понятно, что на самом деле вопрос продовольственной безопасности станы стоит очень остро.

Но без рывка в научной сфере его решение невозможно. Эти задачи сегодня поставлены перед всей научной общественностью России, и в частности перед нашим высшим образовательным учреждением. В истории ГГАУ имеется уникальный, богатый научно-практический опыт, обращение к которому особенно актуально в современных экономических условиях.

Возникновение первого на Северном Кавказе высшего учебного заведения началось с Декрета Совета народных комиссаров Терской республики от 5 октября 1918 г. о создании Первого советско- 
го политехнического института (с 1923 г. преобразован в Горский политехнический институт (ГПИ), а затем в 1928 г. - в Горский сельскохозяйственный институт (ГСХИ), а с 1992 г. вуз получил статус университета и стал Горским государственным аграрным университетом (ГГАУ). Специально институту в 1918 г. были выделены здания, занимаемые бывшим Первым реальным училищем ${ }^{1}[5$; 6, 7-8] (фото 2), с прилегающими к нему бывшими усадьбами Я.Е. Папкова, владевшего до революции водяной мельницей ${ }^{2}[7,7$ об. - 8]; зданиями бывшего Николаевского 6-классного училища ${ }^{3}[5 ; 6$, 8] (фоото 3) и принадлежащими к нему усадьбами. Кроме перечисленного Совнарком республики закрепил за институтом участок пахотной земли с фруктовым садом (всего сто шестьдесят десятин) со

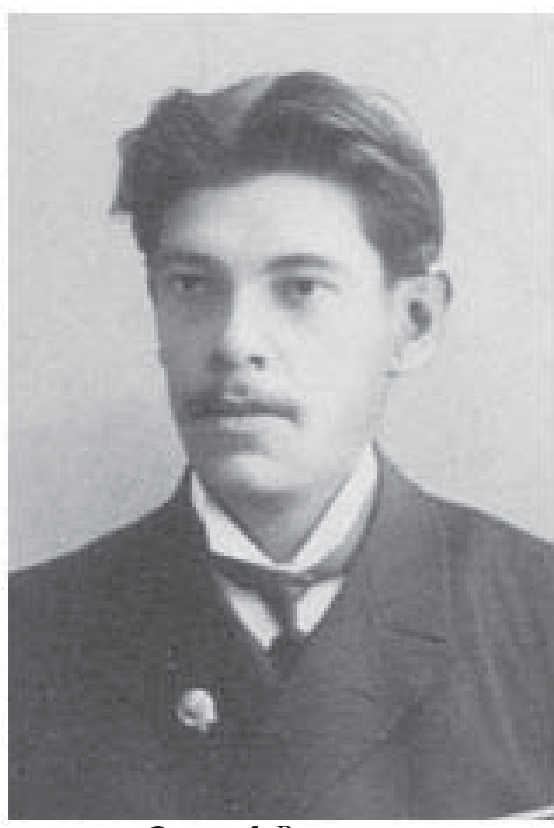

Фото 4. Владимир

Федорович Раздорский дил совместные исследования по фризиологии [8, 11].

Нужно вспомнить и других исследователей и педагогов вуза. Первым ректором института в 1918 г. стал профрессор по кафедре механики Иосиф Гаврилович Есьман, который до Первой мировой войны преподавал в петербургских институтах - Политехническом, Электромеханическом (совр. ЛЭТИ им. В.И. Ленина) и Институте гражданских инженеров (совр. СПбГАСУ) [8, 38]. Его труд «Курсы гидравлики водяных двигателей и центробежных насосов» стал учебным пособием для всех вузов СССР, много раз переиздавался, переведен на иностранные языки. В этом исследовании ученый изложил математически обоснованную гидравлическую теорию газов в металлургических печах, которая используется при всеми хозяйственными и жилыми гидравлических расчетах по сей день («формулы профессора Есьмана»). С 1913 г. ученый был научным консультантом ряда министерств и ведомств в Санкт-Петербурге: министерства торговли и промышленности, министерства путей сообщения, главного артиллерийского управления и др.

Став ректором ГПИ, Иосиф Гаврилович как крупный специалист одновременно был назначен исполняющим обязанности Народного комиссара труда и промышленности Терской области. Именно он подписывал купюры, которые выпускало Владикавказское отделение Госбанка в годы гражданской войны, когда ослабла центральная власть и во многих регионах страны появились местные деньги (фоomo 5).

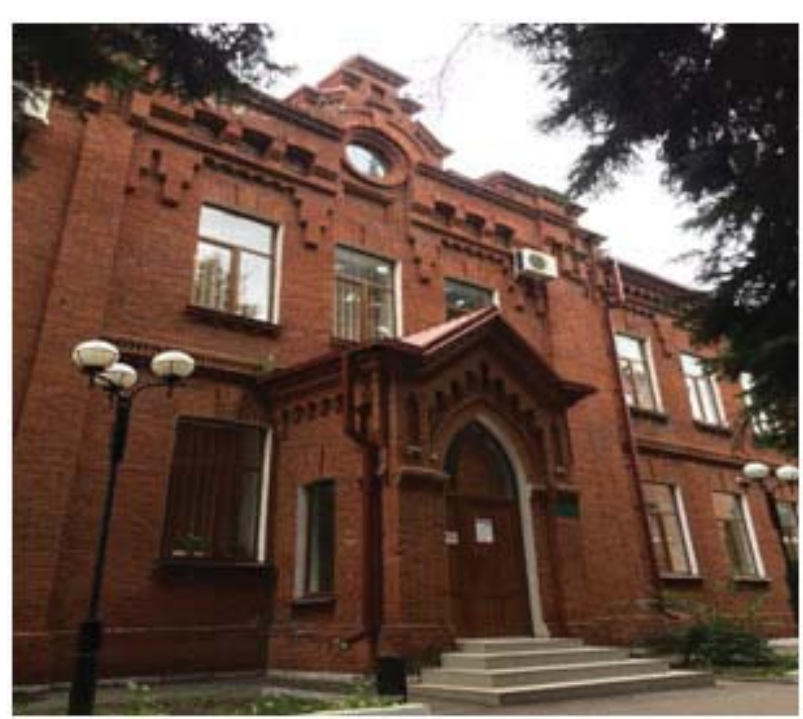

Фото 3. Бывшее здание Николаевского 6-классного училища. Сейчас - библиотека ГГАУ
Большой научный интерес представляют труды профрессора А.М. Панкова - основателя кафедры почвоведения и музея почвоведения, который составил почвенные карты Северной Осетии, Дагестана, Чечни, Кабардино-Балкарии, КарачаевоЧеркессии и Черноморского побережья Кавказа, впоследствии стал директором Московского института почвоведения. Профессор Дукельский - химик, технолог ГПИ, который работал в Германии, Франции и Голландии; профессор, магистр физики Биске, работавший в Страсбургском, Цюрихском и Донском университетах $[8,38]$. Большой вклад в дело сохранения ГПИ внес профессор по теории права Александр Рихардович Гюнтер - бывший приват-доцент Харьковского университета. Александр Рихардович в составе инициативной группы преподавателей ГПИ несколько раз встречался с В.И. Лениным, чтобы отменить решение Народного комиссариата просвещения РСФСР о закрытии 
института и обеспечить его финансирование. Во многом ему это удалось благодаря представителю Горской республики при Совнаркоме РСФСР Марку Гавриловичу Авсарагову. Потому что руководству страны было понятно, что без развития высшей школы и без научных кадров страна была обречена на распад и деградацию1. Тогда, в 20-е годы XX в. фринансирование было очень скудным, часто не хватало средств даже на отопление института, но при этом для вуза выделялись средства на командировки преподавателей и аспирантов не только в московские и петроградские вузы, но и за границу. Так, по окончании института Хасанбек Бахоевич Дзанагов был направлен в 1926-1928 гг. в командировку в Данию и по возвращении издал книгу «Сельское хозяйство Дании» [9]. В 1925 г. во время заграничной командировки в Берлин В.Ф. Раздорский на заседании Германского ботанического общества представил свою теорию (теория Раздорского) и положил тем самым конец ранее господствовавшему в науке учению швейцарского исследователя Симона Швенденера. В монографии «Анатомия растений» ученым была изложена его теория, в которой проведены аналогии между анатомическим строением растений и конструкцией железобетонных сооружений [10], ведь по первой специальности В.Ф. Раздорский был инженермеханик, окончивший не только Первое реальное училище, заложившее начальную базу его военноинженерному образованию, но затем и Московское высшее техническое училище. Это один из немногих случаев, когда в западной науке была принята теория советского ученого под его именем. В.Ф. Раздорский, стараниями которого во многом был создан наш вуз, похоронен во дворе ГГАУ (фото 6). Его могила находится напротив здания бывшего Николаевского училища, инспектором которого был его отец - надворный советник Федор Иванович Раздорский, и рядом с бывшим Первым реальным училищем, в котором он учился и на базе которого было открыто первое на Северном Кавказе высшее учебное заведение, которому он посвятил свою жизнь.

Одним из ректоров ГСХИ (в 1922 г.) был Сергей Алексеевич Гатуев - хранитель минералогического и геологического музея Российской академии наук, ученик профессора Н.И. Андрусова, ставший первым в Осетии профессором геологии. Сергей Алексеевич был одним из 12 детей Алексея Гатуева, настоятеля владикавказской церкви Рождества Пресвятой Богородицы (Осетинской церкви), который был преподавателем, а затем и руководителем Владикавказского осетинского женского приюта (Ольгинского женского училища). Как Сергей, так и остальные дети А. Гатуева получили хорошее образование: сын Константин (Дзахо) стал известным

${ }^{1}$ В условиях постоянной оптимизации образования и сокращения финансирования такие же задачи часто приходится решать и нынешнему ректору ГГАУ профессору В.Х. Темираеву.

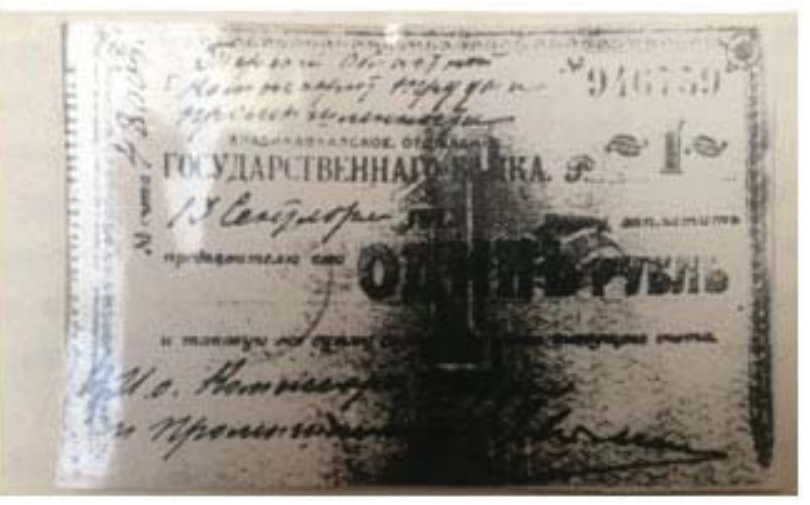

Фото 5. Денежный знак за подписью И.Г. Есьмана

писателем, автором знаменитых произведений «Зелимхан», «Гага-аул» и др.; дочери работали учительницами [11].

Одним из проректоров ГСХИ был профессор Давид Абрамович Тарноградский, в прошлом одноклассник В.Ф. Раздорского по Первому реальному училищу во Владикавказе, который так же, как и Владимир Федорович, знал в совершенстве французский, английский, итальянский и даже японский языки, учился в Сорбонском университете в Париже, а с 1918 г. начал работу в Горском политехническом институте, став в 1927 г. профессором, заведующим кафедрой зоологии ГСХИ, основал на Реданте Северокавказскую гидробиологическую станцию. Под редакцией Давида Абрамовича издавались «Работы Северокавказской гидробиологической станции при ГСХИ» на русском и французском языках в течение 25 лет. В 1938 г. он был инициатором открытия во Владикавказе медицинского института (СОГМА), изучал вопросы биологии северокавказских водоемов. Его работы получили признание во всем мире и сыграли весомую роль в ликвидации малярийного комара на юге России [12]. Д.А. Тарноградский был основателем зоологического отдела музея ГГАУ, в одном из помещений которого до сих пор находится его рабочий кабинет, с его же мебелью, книгами, журналом, который он издавал на двух языках, с его письменным столом,

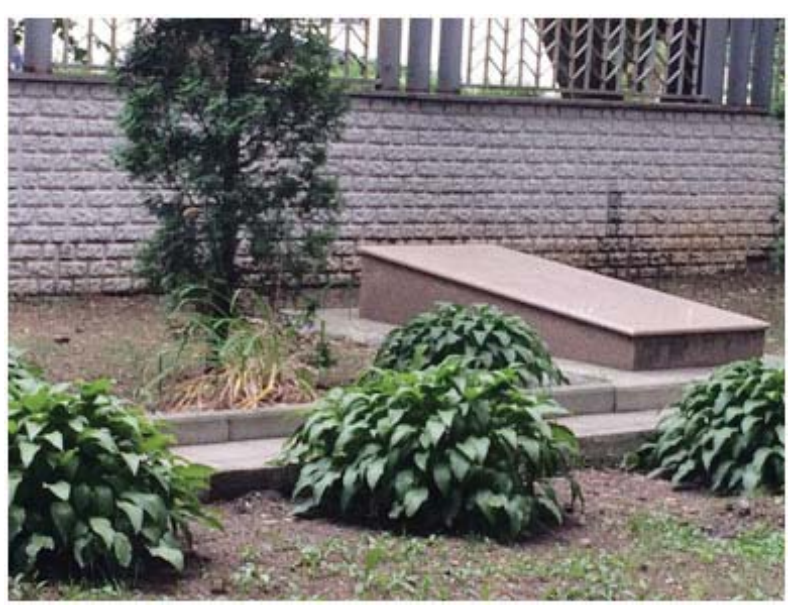

Фото 6. Могила В.Ф. Раздорского во дворе ГГАУ 


\section{ЧШИЕВА М.Ч. СТРАНИЦЫ ПРОШЛОГО ГГАУ...}

личными вещами, полевой сумкой, зонтом. Такое ощущение, что ученый ненадолго уехал в экспедицию (фoomo 7).

Несведущего человека может удивить, что экспонаты зоологического музея (их более 1 000), которые были собраны исследователем в научных экспедициях на Кольском полуострове, Белом море (1922 г.), в Персии (1923 г.), на Баренцевом море (1956 г.), на озере Байкал (1965г.): рептилии, амфибии, иглокожие, хордовые, птицы - расставлены по степени родства на шикарных резных витринах, выполненных из дорогой породы букового дерева. Оказывается, эта резная мебель попала в музей из ювелирного салона его отца - Абрама Яковлевича, владикавказского второй гильдии купца, который до революции занимался изготовлением и торговлей золотыми, серебряными вещами и часами в своем магазине на Александровском про-
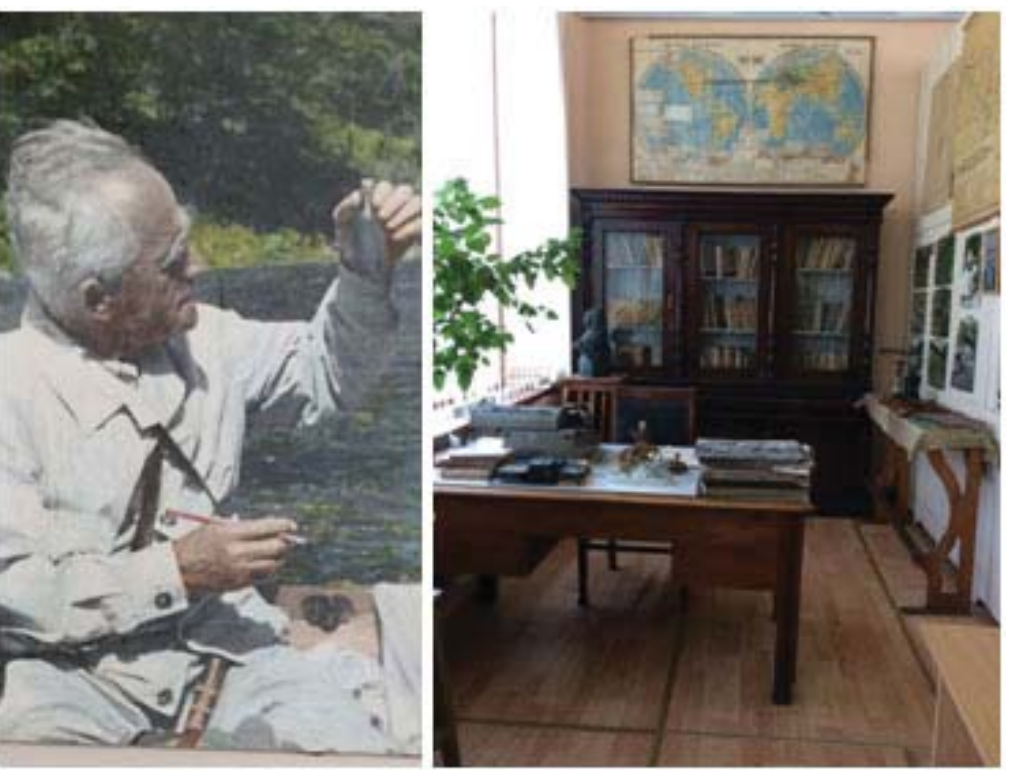

Фomo 7. Д.А. Тарноградский, его кабинет в Горском ГАУ спекте $[13,175]$ (современный Проспект Мира), а также был председателем правления Еврейского кредитного товарищества во Владикавказе [14, 255]. Вот откуда в зоологическом музее такая роскошь.

Сегодня в экспозиции музея ГГАУ - кроме зоологического, еще четыре раздела: исторический, почвенный, минералогии, палеонтологии и охраны окружающей среды. Здесь до сих пор незримо присутствует дух Первого реального училища. В музее coxpaнились рельесные карты разных частей земного шара, геодезические приборы и коллекция минералов, а в актовом зале в настоящее время размещена историческая часть экспозиции. До 1920 г. в этом зале, одном из самых презентабельных во Владикавказе, обычно проходили балы и другие светские мероприятия. Как правило, торжества сопровождали музыканты, располагавшиеся в специально предусмотренных и сохранившихся до сегодняшнего дня на уровне второго этажа балконах. Музей сегодня стал идеологическим, образовательным, научным и просветительным подразделением вуза, хранилищем памятников истории,

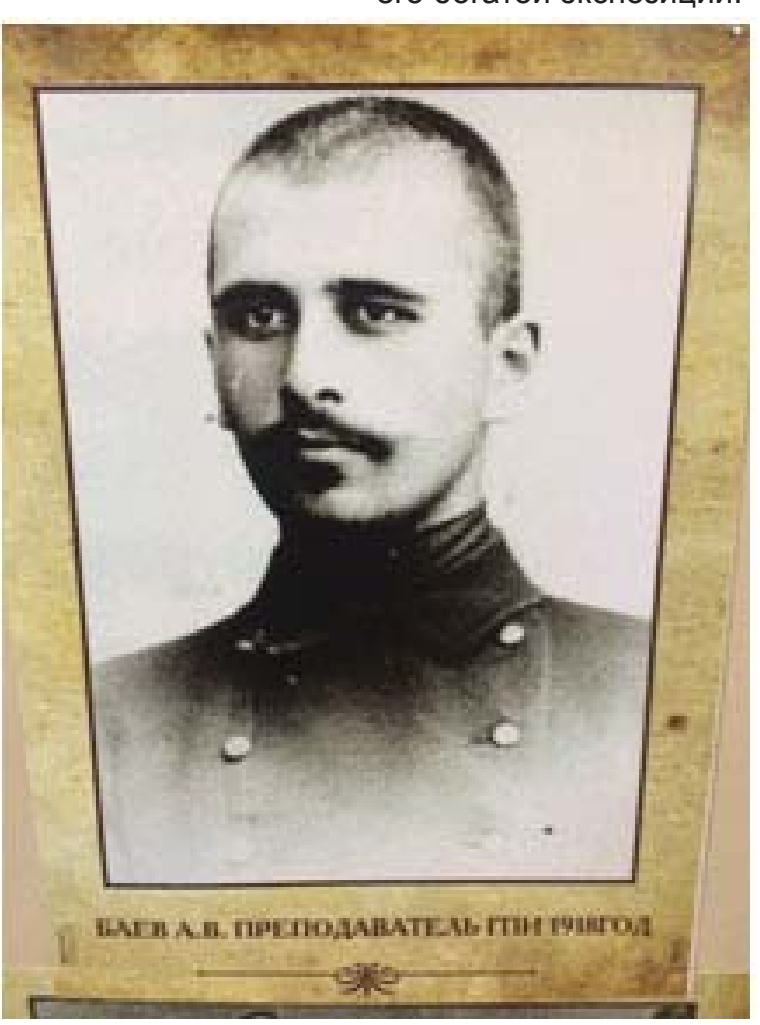

Фото 8. Андрей Васильевич Баев

естественной истории, материальной и духовной культуры. Благодаря высоко поставленной планке качества работы, профессионализму его основателей и коллективу сотрудников, которыми сегодня руководит Дзерасса Засеева, каждый посетитель музея, даже самый юный, не останется без внимания. Дзерасса Созыровна проведет экскурсию по всем залам музея и с необыкновенной теплотой и искрой в глазах расскажет о выдающихся ученых ГГАУ, творивших его историю, о каждом экспонате его богатой экспозиции.

Преподавателем нашего вуза был и брат известных не только в Oceтии, но и далеко за ее границами Гаппо ${ }^{5}[8,5]$ и Чермена Баевых - Андрей Васильевич Баев (фото 8). Еще с 1918 г. он начал работу в ГПИ, в 1919 г. стал доцентом, а затем профессором математики ГСХИ, входил в состав «Совета при правителе Осетии» [15].

Перечислить имена всех ученых университета, стоявших у истоков его основания и известных не только в России, но и в мире, формат данной статьи просто не позволяет. Деятельность каждого исследователя (Л.П. Семенова, Л.Б. Беме, В.И. Де-Фриу, Н.А. Крестова, Г.Ф. Мухина, И.М. Иосифова, Е.Ф. Павлова, Ф.Я. 
Коновалова и др.) достойна специальной монографии, но объединяет их то, что они были представителями русской дореволюционной классической академической школы, на основе которой была затем создана советская школа, признанная лучшей в мире.

Труды этих выдающихся ученых до сих пор являются востребованными. Но в большей степени они востребованы не в нашей стране, а за рубежом. Например, в Китае по проектам И.Г. Есьмана [16] строятся мини-электростанции. В мировой науке признанной стала теория В.Ф. Раздорского, труды которого переведены на многие иностранные языки. По учебникам ботаники Владимира Федоровича учились студенты всех биологических вузов странь до 50-х годов XX века. Труды В.Ф. Раздорского по «Архитектонике растений» [17] активно используют японские архитекторы при проектировке зданий в сейсмоопасных зонах.

Прототип современного ксерокопировального аппарата - фотонаборную машину еще в 30-е годы XX века спроектировал и изготовил, как и десятки других изобретений, преподаватель ГСХИ (ныне ГГАУ), сын известного в Осетии общественного деятеля Афанасия Абрамовича Гассиева - Виктор Гассиев [18]. Интересна и богата история, связанная с именами первых выпускников - профессоров К.И. Трофименко, Х.Б. Дзанагова, А.Б. Саламова, которые стали выдающимися учеными и внесли большой вклад в развитие и становление различных отраслей сельского хозяйства.

Труды современных ученых Горского ГАУ являются не менее признанными в научной среде. В вузе созданы школа агрохимии под руководством доктора С.-Х. наук С.Х. Дзанагова: Созырко Хасанбекович разработал модели плодородия основных типов почв Северного Кавказа, технологии эффрективного применения минеральных и органических удобрений в сельском хозяйстве; научная школа селекции и семеноводства кормовых и нетрадиционных культур под руководством доктора с.-х. наук С.А. Бекузаровой: Сарра Абрамовна вывела более десятка сортов клевера, нашедших широкое применение в сельскохозяйственном производстве; научная школа земледелия доктора с.-х. наук Э.Д Адиньяева; научная школа по аграрной экономике, основанная доктором С.-х. наук Б.Б. Басаевым; научная школа биологической азотфиксации, основанная доктором С.-х. наук А.Т. Фарниевым; научная школа по повышению технологических качеств продукции сельского хозяйства, основанная В.Р. Каировым; научная школа механизации сельского хозяйства, созданная доктором с.-х. наук А.Б. Кудзаевым, изобретения которого были презентованы в Германии, где они получили высокую оценку; и др.

Среди ученых, работавших в области механизации садоводства, хорошо известно имя доктора технических наук, профессора Б.Х. Кульчиева. Этот талантливый ученый сумел создать в Горском ГАУ крупнейшую в СССР Лабораторию садовых машин, тесно сотрудничавшую с конструкторским бюро «Плодсельхозмаш», Всесоюзным институтом сельскохозяйственного машиностроения, Всероссийским институтом садоводства и питомниководства и т. д. Совместно с коллективами этих учреждений удалось разработать прекрасные образцы плодоуборочной техники. Это плодоуборочные комбайны: МПУ-1, МПУ-1А, МПУ-1М, ВУМ-15А и другие [9, 358].

Однако в условиях современной российской действительности эти научные разработки с большим трудом пробивают дорогу по внедрению в производство, которое сегодня становится невыгодным. «Например, тракторный завод, принадлежащий объединению «Ростсельмаш», находящийся в Канаде и получивший в 2012 году прибыль в размере 16,4 млн долл., в российских условиях имел бы убыток 21,7 млн долл., т. е. не мог бы работать. Именно налоги - главная статья, определяющая убыточность предприятия в России. Завод в Канаде в 2012 году заплатил в виде налогов 47,9 млн долл.; в России такой завод должен заплатить 74 млн долл., т. е. на 26,1 млн долл. больше. К тому же в Канаде кредиты завод получает под 2,3 \%, а электроэнергия в два раза дешевле... В США, например, нет НДС, вместо этого гибкий налог с продаж (от 5-11 \%)» [2]. Т. е. в таких неравных условиях российское хозяйство всегда будет в убыточных условиях.

По мнению советника Президента РФ академика С.Ю. Глазьева, причина происходящего - в гибридной войне, которую ведет наш геополитический противник против России. США и «вся семерка» обеспечивают свое экономическое, технологическое, финансовое, военное, информационное превосходство за счет присваивания интеллектуальной ренты и контроля над экономической периферией постсоциалистических стран. России, в экономике которой отсутствует стратегическое планирование, навязывается монетаристская макроэкономическая политика и через инструкции Центральному Банку РФ осуществляется «пристегивание к доллару» ее фринансовой системы [1]. Поэтому в применяемой сегодня хозяйственной модели экономический рост достигается, в первую очередь, не за счет внедрения новых технологий, а за счет увеличения себестоимости производимой продукции, путем повышения ее издержек: за счет постоянного роста цен на услуги ЖКХ, бензин, повышения налогов (НДС), процентных ставок по кредитам.

В 30-50-е XX века наша экономика работала по принципиально другой хозяйственной модели, которая позволяла ежегодно, начиная с 1947 г., на 30 \% снижать цены на производимую продукцию (а ведь прошло только 2 года после окончания Великой Отечественной войны!). И в первую очередь осуществлялось это за счет созданной самодостаточной модели экономики, на основе широкого внедрения научных разработок, сокращавших в ре- 
зультате издержки производства, что приводило к ежегодному снижению цен, и это осуществлялось в СССР вплоть до 1953 г., и, соответственно, росло благосостояние населения.

В 1948 г., когда Европа еще восстанавливала хозяйство от последствий разрушительной войны, в СССР была принята не имеющая аналогов в мировой практике пятнадцатилетняя программа научного регулирования природы, разработанная на основе трудов выдающихся русских и советских агрономов В.В. Докучаева, П.А. Костычева и В.Р. Вильямса.

«Согласно плану преобразования природы началось грандиозное наступление на засуху путем посадки лесозащитных насаждений, внедрения травопольных севооборотов, строительства прудов и водоемов (Поволжье, Западный Казахстан, Северный Кавказ, Украина). Сила этого плана была в единой воле, комплексности и масштабности. По этому плану за 15 лет предполагалось создать 8 крупных государственных лесозащитных полос общей протяженностью свыше 5300 километров, на полях колхозов и совхозов нужно было создать защитные лесонасаждения общей площадью 5709 тысяч гектаров, и уже к 1955 году в колхозах и совхозах предполагалось построить 44228 прудов и водоемов. Все это в соединении с передовой советской агротехникой обеспечило бы высокие, устойчивые, не зависящие от капризов погоды урожаи на площади свыше 120 миллионов гектаров. Урожая, собранного с этой площади посевов, хватило бы, чтобы прокормить половину жителей Земли. Центральное место в плане занимало полезащитное лесоразведение и орошение» [19]. Созданные лесополосы и водоемы должны были существенно разнообразить флору и фауну СССР. Таким образом, план совмещал в себе задачи охраны окружающей среды и получения высоких устойчивых урожаев. Частично эта программа реализуется сегодня в Китае, США, Западной Европе в виде создаваемых зеленых каркасов [19].

И в нашем вузе также есть подвижники, которые понимают: чтобы жара не накрыла весь юг России и земля не болела, нужно сажать деревья, разбивать сады массово и повсеместно. Один из них - профессор кафедры агрохимии и почвоведения ГГАУ, директор НИИ агроэкологии Азан Владимирович Газданов. В питомнике университета, который он заложил на окраине Владикавказа, выращивают по 60-70 тыс. саженцев в год, одних только яблонь здесь больше 110 сортов, груш и слив - до 22. Са- женцы А.В. Газданова востребованы по всему Северному Кавказу. Массовое разведение садов не только обеспечивает продовольственную безопасность страны, стимулирует перерабатывающую промышленность, но и способствует улучшению почв, в целом положительно влияет на экологию. Небольшой такой сад способен добыть из осадков влаги несколько десятков тонн. Кроме того, сады привлекают птиц, так идет борьба с вредителями зеленых насаждений. Сады, леса позволяют предохранять поля от суховеев. Пример деятельности Азана Владимировича показывает, что нужно не природу или климат ругать, а предпринимать практические действия, чтобы делать науку востребованной, а экономику - защищенной от внешних угроз, то есть самодостаточной.

Столетний научно-практический опыт сотрудников Горского ГАУ, и в целом советской и современной отечественной науки, должен быть востребован для обеспечения продовольственной безопасности нашей страны, а внедрение научных стартапов, разрабатываемых учеными нашего университета, привело бы к снижению издержек производства сельхозпродукции и росту благосостояния населения страны.

\section{ПРИМЕЧАНИЯ}

Здесь же на 2-м этаже находилась домовая церковь 1-го реального училища. Сейчас в этом здании размещается корпус агрономического факультета. «Это одно из последних зданий, построенное в стиле модерн накануне Первой мировой войны, которое может служить образцом высокого мастерства кирпичной кладки (работа Артамонова). Над главным входом во 2-м этаже разместился большой актовый зал с балконами. Вместо обычного навершия, почти обязательного атрибута модерна, на крыше здания была установлена надстройка для астрономических наблюдений» [20] (фото 1). Современный главный корпус ГГАУ, выходящий фасадной частью на улицу С.М. Кирова, где до революции располагались штаб 21-й пехотной дивизии, Управление Владикавказского воинского начальника, Терская инженерная дистанция и военная гауптвахта, до 70-х гг. XX в. институту не принадлежали (фото 1).

2 Папков Яков Евдокимович - бывший владелец мукомольной водяной мельницы по Надтеречной улице.

${ }^{3}$ Сейчас в этом здании находится библиотека ГГАУ (фото 3).

${ }^{4}$ Терпугов Александр Иванович - уездный предводитель дворянства, активный член Владикавказского благотворительного общества при Армянской церкви. Его имение находилось в 10 км от Владикавказа, с садом, полевыми угодьями и постройками, для организации учебного хозяйства сельскохозяйственного факультета. Сегодня здесь построены ветеринарный и биотехнологический факультеты ГГАУ.

${ }^{5}$ Гаппо Баев был в числе представителей осетинской интеллигенции, которые организовали Политехническое общество с целью создания во Владикавказе политехнического института.

\section{ЛИТЕРАТУРА}

1. Глазьев С.Ю. «Мы слишком долго отступали...». Академик РАН Сергей Глазьев о странностях современной гибридной войны, ее возможных последствиях и альтернативах // Литературная газета. № 21(6645) от 30 мая - 5 июня 2018. C. 3-4.

2. Симчера В.М. Перемен не будет // Газета "Завтра» от 29.05.2018. [электронный ресурс]. https://mak-50.livejournal. com/1422196.html

3. Валентин Катасонов. Россию душит сетевой вампир [электронный ресурс] http://reosh.ru/valentin-katasonov-rossiyudushit-setevoj-vampir.html

4. Сергей Кара-Мурза. Миф об экономическом кризисе в СССР [электронный ресурс]. http://ecology.md/page/sergejkara-murza-mif-ob-ekonomichesko

5. Центральный государственный архив РСО-А. Ф.8., оп. 1, ว. 115.

6. Центральный государственный архив РСО-А, инв. № 1362. ЛЛ. 195-199. 
7. Центральный государственный архив РСО-А. Ф. 224 оп. 1 , дело 56. ЛЛ. 7 об.-8.

8. Дорогой созидания и прогресса. 95 лет Горскому государственному аграрному университету / Ответственный редактор В.Х.Темираев. - Владикавказ: Проект-Пресс, 2013. 544 c.

9. Дзанагов Х.Б. Сельское хозяйство и молочная индустрия в Дании. - Владикавказ: Северо-Осетинский институт краеведения, 1928. 117 с.

10. Раздорский В.Ф. Анатомия растений. - М.: Советская наука, 1949. 594 с.

11. Лариса Гостиева. Протоиерей Алексий Гатуев. «Дарьял», 2007, № 1. [электронный ресурс]. http://www.darialonline.ru/2007_1/gostieva.shtml

12. Тарноград̄ский Д.А. Анофрелогенные ландшафоты Северного Кавказа. - Дзауджикау: Гос. Изд. Сев.-Осет. АССР, типография им. 11 авг. 1918 г. в Грозном, 1948. 138 с.

13. Терский календарь на 1914 2. - Владикавказ: Издание Терского Областного Статистического Комитета, 1913. 461 с.
14. Кредитные учреждения Терской области. Терский календарь на 1911 г. - Владикавказ: Издание Терского Областного Статистического Комитета, 1910. 578 с.

15. Марзоев И.Т. Род Баевых в истории Осетии (XIX - начале $X X \quad$ в.) [электронный pecypc].http://izvestia-soigsi.ru/ izvestia/2017/24/i-t-marzoev.pdf

16. Есьман И.Г. Гидравлика. СПб.: Электротехнический Институт Императора Александра III, 1910. 184 c.

17. Раздорский В.Ф. Архитектоника растений. - М.: Социалистическая наука, 1955. 432 с.

18. Кануков Н.Д. Изобретатель В.А. Гассиев. - Орджоникидзе: Северо-Осетинское книжное изд-во, 1958. $101 \mathrm{c.}$

19. Елена Счастливая. Последний удар Сталина - Сталинский план преобразования природы. 2015. [электронный реcypc].http://stalinskij-plan-preobrazovaniya-prirody

20. Цаллагов С.Ф. Учебные заведения Владикавказа. [электронный ресурс]

http://www.darial-online.ru/2017_5/tsallagov.shtml

\section{PAGES OF THE PAST GGAU (Mountainous State Agrarian University): A LOOK INTO THE FUTURE (TO THE 100TH ANNIVERSARY OF THE ESTABLISHMENT)}

\section{CH. Chshieva}

Ph. D., associate Professor of philosophy and history, Gorsky state agrarian University (hacht@mail.ru).

Abstract. The Mountainous state agrarian University marks 100 years old. Not every higher educational establishment can be proud of such a rich history. The University was born in the conditions of revolution, civil war and foreign intervention. At this difficult time, in Ossetia, as in Russia in general, the agrarian issue remained unresolved, and there was a lack of scientific personnel and educational institutions to train them. Today, 100 years later, the University as the country in general faces truly revolutionary tasks again, as it used to in the period of its establishment. These tasks have been set by the President of the Russian Federation in the May decrees to ensure food security of the country, and as a consequence, to enter the list of five developed countries of the world, which is achievable only in the case of a breakthrough in the scientific sphere.

The Agrarian University has a rich scientific-practical experience. The article analyzes the activities of scientists whose names are associated with the vital pages of the University history. Thus, the scientific-practical experience gathered for one hundred year term of the Mountainous State Agrarian University history has not been expendable. Agreeing with the point of view of the Russian presidential adviser academician S. Glazyev, it should be noted that in the context of the hybrid war pulling resources from Russia and other postsocialist countries, food security plays a huge role, which cannot be achievable without the development of agricultural science.

Keywords: the first Soviet Polytechnic Institute, the development of agricultural science in the North Caucasus, the scientific school of V.F. Razdorsky, of D.A. Tarnogrodsky, S.H. Dzanagov, S.A. Bekuzarova, B.B. Basayev.

\section{REFERENCES}

1. Glazyev S. Yu. «My slishkom dolgo otstupali...». Akademik RAN Sergey Glazyev o strannostyakh sovremennoy gibridnoy voyny. eye vozmozhnykh posledstviyakh i alternativakh // Literaturnaya gazeta. № 21(6645) ot 30 maya - 5 iyunya 2018. S. 3-4.

2. Simchera V.M. Peremen ne budet. // Gazeta «Zavtra» ot 29.05.2018. [elektronnyy resurs]. https://mak-50.livejournal.com/1422196. html

3. Valentin Katasonov. Rossiyu dushit setevoy vampir [elektronnyy resurs] http://reosh.ru/valentin-katasonov-rossiyu-dushit-setevojvampir.html

4. Sergey Kara-Murza. Mif ob ekonomicheskom krizise v SSSR [elektronnyy resurs]. http://ecology.md/page/sergej-kara-murza-mifob-ekonomichesko

5. Tsentralnyy gosudarstvennyy arkhiv RSO-A. F.8.. op. 1. d. 115.

6. Tsentralnyy gosudarstvennyy arkhiv RSO-A. inv. № 1362. LL. 195-199.

7. Tsentralnyy gosudarstvennyy arkhiv RSO-A. F. 224. op.1. delo 56. LL. 7 ob.-8.

8. Dorogoy sozidaniya i progressa. 95 let Gorskomu gosudarstvennomu agrarnomu universitetu / Otvetstvennyy redaktor V.Kh. Temirayev. - Vladikavkaz: Proyekt-Press. 2013. 544 s.

9. Dzanagov Kh.B. Selskoye khozyaystvo i molochnaya industriya v Danii. - Vladikavkaz: Severo-Osetinskiy institut krayevedeniya 1928. 117 s.

10. Razdorskiy V.F. Anatomiya rasteniy. - M.: Sovetskaya nauka. 1949. 594 s.

11. Larisa Gostiyeva. Protoiyerey Aleksiy Gatuyev. "Darial». 2007. № 1. [elektronnyy resurs]. http://www.darial-online.ru/2007_1/ gostieva.shtml

12. Tarnogradskiy D.A. Anofelogennyye landshafty Severnogo Kavkaza. - Dzaudzhikau: Gos. Izd. Sev.-Oset. ASSR. tipografiya im. 11 avg. 1918 g. v Groznom. 1948. 138 s.

13. Terskiy kalendar na 1914 g. - Vladikavkaz: Izdaniye Terskogo Oblastnogo Statisticheskogo Komiteta. 1913.461 s.

14. Kreditnyye uchrezhdeniya Terskoy oblasti. Terskiy kalendarna 1911 g. - Vladikavkaz: Izdaniye Terskogo Oblastnogo Statisticheskogo Komiteta. 1910. $578 \mathrm{~s}$.

15. Marzoyev I.T. Rod Bayevykh v istorii Osetii (KhIKh - nachale KhKh v.) [elektronnyy resurs].http://izvestia-soigsi.ru/izvestia/2017/24/ i-t-marzoev.pdf

16. Esman I.G. Gidravlika. SPb.: Elektrotekhnicheskiy Institut Imperatora Aleksandra III. 1910. $184 \mathrm{~s}$.

17. Razdorskiy V.F. Arkhitektonika rasteniy. - M.: Sotsialisticheskaya nauka. 1955. 432 s.

18. Kanukov N.D. Izobretatel V.A. Gassiyev. - Ordzhonikidze: Severo-Osetinskoye knizhnoye izd-vo. $1958.101 \mathrm{~s}$

19. Elena Schastlivaya. Posledniy udar Stalina - Stalinskiy plan preobrazovaniya prirody. 2015. [elektronnyy resurs].http://stalinskijplan-preobrazovaniya-prirody

20. Tsallagov S.F. Uchebnyye zavedeniya Vladikavkaza. [elektronnyy resurs]

http://www.darial-online.ru/2017_5/tsallagov.shtml 